\title{
The Theory of IE Assembly Line Balance and Optimization
}

\author{
Mao Yin ${ }^{1, a^{*}}$, Wei Jiang ${ }^{2, b}$ \\ ${ }^{1}$ School of Mechanical Engineering Dalian Vocational \& Technical College Dalian, China. \\ 2Dalian Zhongche Locomotive Co. Ltd. Technology Department, China. \\ amydxyx_2011@163.com, bweisunjiang@sina.com
}

Keywords: IE theory; balance of assembly line; ECRS; optimization

\begin{abstract}
This article related to industrial engineering theory in enterprise production management, by way of example describes the basic idea of the method a company truck assembly line balance improvement. Combined with the practical problems in production line system analysis, and put forward the feasible optimization scheme, and to improve the solution were analyzed before and after the production line balancing rate is raised, the purpose of ascension capacity, the actual effect is obvious.
\end{abstract}

\section{Introduction}

With increased competition and locomotive industry development, manufacturing workers in the operation is not standard, site layout is not reasonable, the production system bottlenecks, and so on problems will emerge. So the stand or fall of workshop layout can directly affect the overall level of enterprise production system, but a good layout of production line balance is the key[1]. Based on the theory of industrial engineering to improve, on the basis of analysis of bogie assembly line balancing problem of an enterprise, through the use of industrial engineering research methods and means, make the production rhythm of each workstation consistent, optimized assembly line balance, the enhancement enterprise's core competitiveness.

\section{Improvement Methods Related to Assembly Line Balance}

The general definition of assembly line balance is as follows: production assembly process consists of a series of assembly work elements which can't be further subdivided, every element is corresponding to a certain operation time (standard work time) [2]. Successive constraint relations exist among some of the work elements in assembly sequence. The assembly line balancing problem aims at minimizing the number of needed work stations by incorporating all work elements properly and dispatching them to all work stations of the assembly line under this premise that successive constraint relations must be ensured and every assembly work station's time can't exceed a given production rhythm. Or under the condition of work order constraint relations, all work elements properly are assigned to a given number of workstations to make the rhythm time shortest on an assembly line.

Calculation Method. Assembly line balancing is one of the important indicators of measuring the level of production process. And the assembly production balance rate is higher, the greater efficiency which production line makes[3].

$$
\text { line balance rate } \eta=\left[\text { total process time } /\left(C T^{*} \text { numbers of processes }\right)\right]^{*} 100 \%
$$

Where $C T$ : the biggest standard working time of production processes, that is, according to the definition of production rhythm, production line balance must meet the following two conditions:

a) production rhythm $\geq$ process time

b) $\Sigma$ (production rhythm-process time) is minimum

Balancing Principle of Production Line. Adjust operation time of work elements of every process does not exceed production line's rhythms but don't violate the process sequence, and reduce the number of processes as much as possible. Loss time in each process as little as possible, and keep each more uniform, minimize the loss rate of assembly time. 
Effect Evaluation of Assembly Line Balancing. The effect of assembly line balancing is evaluated by the index of Balance $\operatorname{Delay}\left(B_{d}\right)$, which also is called time loss coefficient $\left(\varepsilon_{L}\right)$. Balance Delay is a percentage value which is calculated by comparing a total idle time on products online to the total time on the assembly line from beginning to end. As the following formula:

$$
B_{d}=\left(N \times C-t_{t}\right) /(N \times C) \times 100 \%
$$

$N$-the number of processes, $C$-the theoretical rhythm, $t_{t}$-total work time.

As to the values of $B_{d}$, evaluation conclusion of three intervals is as the following, such as Table 1.

Table 1 Standard of effect evaluation of assembly line balancing

\begin{tabular}{|c|c|}
\hline Balance delay results & The results of the evaluation (assembly line) \\
\hline$B_{d} \leqq 10 \%$ & excellent \\
\hline $10 \%<B_{d}<20 \%$ & fine \\
\hline$B_{d} \geqq 20 \%$ & bad \\
\hline
\end{tabular}

Smoothness index $S I$ is used to measure the distribution of working time between the working hours in the assembly line. At the same time, it is also an important indicator to reflect the working time of each station. The smaller the smoothness index number, the smaller the working time fluctuation between the working stations of the assembly line, the better the balance effect. Its formula is as follows:

$$
S I=\frac{1}{N} \sqrt{\sum_{i=1}^{N}(C . T-t(i))^{2}}
$$

Form in: SI represents the smoothing index; C.T represents the maximum working time; $t(i)$ represents the actual working process; the $N$ represents the number of bits.

Improvement Methods. During the process of balancing assembly lines, use the related theories of IE and the analysis principle of ECRS to improve work. For the process which takes a long time, some measures can be taken[4]:

(1) Divide operation and move some to the short time-consuming processes;

(2) Use tools or machine to improve work and shorten hours;

(3) Improve the mechanical efficiency;

(4) Increase workers;

(5) Increase investment of the operation department;

(6) Improve the efficiency of workers and function.

For the process which takes little time, some measures can be taken:

(1) Divide operation, fill some into other short time-consuming processes and cancel them;

(2) Move some part of work out of long time-consuming process;

(3) Incorporate short time-consuming processes.

\section{The Example Analysis}

Introduction of the Status Quo. Due to the limitations of the existing plant area limits the enterprise's future development, in order to adapt to the development of the times, a locomotive plant for a rainy day. Whole transferring. Bogie assembly line balance of existing in the design, increase production capacity makes the enterprise to develop fast and well, achieve industrial upgrading.

By the formula before Improving(1), (2),(3), line balance efficiency calculated as follows.

$\eta=\left[\right.$ the total process time $/ C T^{*}$ operation number $] * 100 \%$

$=[38+54+63+41+38+25+22+38+31+21+40 /(63 * 12)]^{*} 100 \%=58.9 \%$

Balance delay rate is calculated as follows.

$$
B_{d}=\left(N \times C-t_{t}\right) /(N \times C) \times 100 \%=41.1 \%
$$

Smoothness index $S I$ is calculated as follows. 


$$
S I_{1}=\frac{1}{N} \sqrt{\sum_{i=1}^{N}(C . T-t(i))^{2}}=8.22
$$

Improve Countermeasures and Implementation. According to the calculation above can see the production line balancing rate is low, there is a big room for improvement. According to the production line balance method to break up the action, and does not affect the process of case. To fine-tune the adjacent location in the first place, if the effect is not obvious, then rearrange process upset again[5]. Then by using the theory of industrial engineering for further improvement.

Improvement for the First Time. Using ECRS method to improve, first to consider the whole production process. Improved and measured data are shown in table 2.

Table 2 for the first time, to improve the process schedule

\begin{tabular}{|c|c|c|c|c|c|c|}
\hline $\begin{array}{c}\text { The NO. } \\
\text { of the } \\
\text { process }\end{array}$ & $\begin{array}{c}\text { The name of the } \\
\text { process }\end{array}$ & equipment & $\begin{array}{c}\text { The } \\
\text { Numbers }\end{array}$ & $\begin{array}{c}\text { Single work } \\
\text { station } \\
\text { hours/min }\end{array}$ & $\begin{array}{c}\text { Wide } \\
\text { release } \\
\text { rate }\end{array}$ & $\begin{array}{c}\text { Standard } \\
\text { working } \\
\text { hours/min }\end{array}$ \\
\hline 1 & $\begin{array}{c}\text { The foundation } \\
\text { brake assembly }\end{array}$ & $\begin{array}{c}\text { Brake } \\
\text { assembly } \\
\text { station }\end{array}$ & 1 & 48 & 1.05 & 50.4 \\
\hline 2 & $\begin{array}{c}\text { Hard tube piping, } \\
\text { foundation braking } \\
\text { to take over }\end{array}$ & $\begin{array}{c}\text { Piping the } \\
\text { same }\end{array}$ & 1 & 120 & 1.05 & 126 \\
\hline 3 & $\begin{array}{c}\text { Bogie wheel } \\
\text { assembly }\end{array}$ & $\begin{array}{c}\text { Wheel seat } \\
\text { station }\end{array}$ & 1 & 65 & 1.05 & 68.25 \\
\hline 4 & $\begin{array}{c}\text { Wheel rim } \\
\text { lubrication device } \\
\text { assembly }\end{array}$ & $\begin{array}{c}\text { Attachment to } \\
\text { install station }\end{array}$ & 1 & 59 & 1.05 & 61.95 \\
\hline 5 & $\begin{array}{c}\text { Bogie } \\
\text { the Weighing } \\
\text { spring }\end{array}$ & $\begin{array}{c}\text { weighing } \\
\text { platform }\end{array}$ & 1 & 110 & 1.05 & 115.5 \\
\hline 6 & $\begin{array}{c}\text { Car ladder plate } \\
\text { assembly shaft } \\
\text { temperature wiring }\end{array}$ & $\begin{array}{c}\text { Temperature } \\
\text { wiring is } \\
\text { station }\end{array}$ & 1 & 35 & 1.05 & 36.75 \\
\hline 7 & Check, submit & Check station & 1 & 40 & 1.05 & 42 \\
\hline
\end{tabular}

$E$ for Eliminate: the working environment of workshop, covering area and overall layout have effects on Architecture and architecture spray paint two working procedures. other parts also need to spray paint processing workshop, comprehensive considering the enterprise overall efficiency, will form a special paint shop, all the painting processing will be done in the independent area.

$C$ for Combine: according to the investigation to the scene, some process can be combined according to the way of the layout. Such as: basic brake assembly and sand box assembly; A suspension device assembly and fall the traction motor suspension system assembly and bogie wheel assembly: rim lubricating device assembly and sweep the stone and sanding pipe support assembly; Car ladder device assembly, nameplate assembly, so that we can reduce the handling time, improve production efficiency.

$R$ for Rearrange: foundation braking are divided into rigid pipe and hose assembly ,this process takes too much time seriously, so, In the process to do the hard tube assembly, then hose assembly and sweep the stone and sanding pipe support assembly into a process to save time.

$S$ for Simplify: making existing multiple work position, reducing to 7 station, shorten the handling time, at the same time, we can save workshop area, greatly improving the production flexibility.

Improvement for the Second Time. From the table, you can see that the work time working procedure number 5, and working procedure number 20 required are too long. Using general industrial engineering improvement method cannot remove bottlenecks, only increase the operation department can very well solved. So recommending procedure number 5 and process number 20 to 
increase a same, In the same time, according to the action analysis, process 10 with the method of standard work assignment can be shorten working time about $5 \mathrm{~min}$. After improving, the relevant data in the following Table 3.

Table 3 second improve process schedule

\begin{tabular}{|c|c|c|c|c|c|c|}
\hline $\begin{array}{c}\text { The NO. } \\
\text { of the } \\
\text { process }\end{array}$ & $\begin{array}{c}\text { The name of the } \\
\text { process }\end{array}$ & equipment & $\begin{array}{c}\text { The } \\
\text { Numbers }\end{array}$ & $\begin{array}{c}\text { Single work } \\
\text { station } \\
\text { hours/min }\end{array}$ & $\begin{array}{c}\text { Wide } \\
\text { release } \\
\text { rate }\end{array}$ & $\begin{array}{c}\text { Standard } \\
\text { working } \\
\text { hours/min }\end{array}$ \\
\hline 1 & $\begin{array}{c}\text { The foundation } \\
\text { brake assembly }\end{array}$ & $\begin{array}{c}\text { Brake } \\
\text { assembly } \\
\text { station }\end{array}$ & 1 & 48 & 1.05 & 50.4 \\
\hline 2 & $\begin{array}{c}\text { Hard tube piping, } \\
\text { foundation braking } \\
\text { to take over }\end{array}$ & $\begin{array}{c}\text { Piping the } \\
\text { same }\end{array}$ & 2 & 60 & 1.05 & 63 \\
\hline 3 & $\begin{array}{c}\text { Bogie wheel } \\
\text { assembly }\end{array}$ & $\begin{array}{c}\text { Wheel seat } \\
\text { station }\end{array}$ & 1 & 65 & 1.05 & 68.25 \\
\hline 4 & $\begin{array}{c}\text { Wheel rim } \\
\text { lubrication device } \\
\text { assembly }\end{array}$ & $\begin{array}{c}\text { Attachment to } \\
\text { install station }\end{array}$ & 1 & 59 & 1.05 & 61.95 \\
\hline 5 & $\begin{array}{c}\text { the Weighing } \\
\text { spring }\end{array}$ & $\begin{array}{c}\text { Bogie } \\
\text { weighing } \\
\text { platform }\end{array}$ & 2 & 55 & 1.05 & 57.75 \\
\hline 6 & $\begin{array}{c}\text { Car ladder plate } \\
\text { assembly shaft } \\
\text { temperature wiring }\end{array}$ & $\begin{array}{c}\text { Temperature } \\
\text { wiring is } \\
\text { station }\end{array}$ & 1 & 35 & 1.05 & 36.75 \\
\hline 7 & Check, submit & Check station & 1 & 40 & 1.05 & 42 \\
\hline
\end{tabular}

According to the Formula (1), (2) and (3), line balance efficiency is calculated as follows. $\eta=\left[\right.$ the total process time $/ \mathrm{CT}^{*}$ operation number $] * 100 \%$ $=[50.4+63+63+61.95+57.75+36.75+42 /(63 * 7)]^{*} 100 \%=85 \%$

Balance delay rate is calculated as follows.

$$
B_{d}=\left(N \times C-t_{t}\right) /(N \times C) \times 100 \%=15 \%
$$

Improved balance delay rate $B_{d}$ is $15 \%$ between $10 \%$ and $20 \%$, In accordance with the assembly line balancing effect criteria in table 1.,the truck assembly line balancing is up to the level of the good.

Smoothness index $S I$ is calculated as follows.

$$
S I_{1}=\frac{1}{N} \sqrt{\sum_{i=1}^{N}(C . T-t(i))^{2}}=5.19
$$

The Effect Evaluation. To sum up, through the improvement of assembly line balance rate is improved, the smooth coefficient can be reduced, improving the contrast before and after analysis shown as Figure 1 and Figure 2.

\section{Conclusion}

By improving the comparison is not difficult to see, after the improvement of the program to improve the assembly line balance rate to $85 \%$, the balance of the delay rate reduced to $15 \%$. Although there is no ideal target to achieve the balance delay ratio of less than or equal to $10 \%$, the effect of assembly line balancing has reached a good level. Before and after the improvement of the smoothness of the system is also reduced, indicating that the assembly line balancing effect is greatly improved. At the same time, the production efficiency of the assembly line is improved, and the production and management level of the enterprise is improved, and the production management level of the enterprise is improved. 

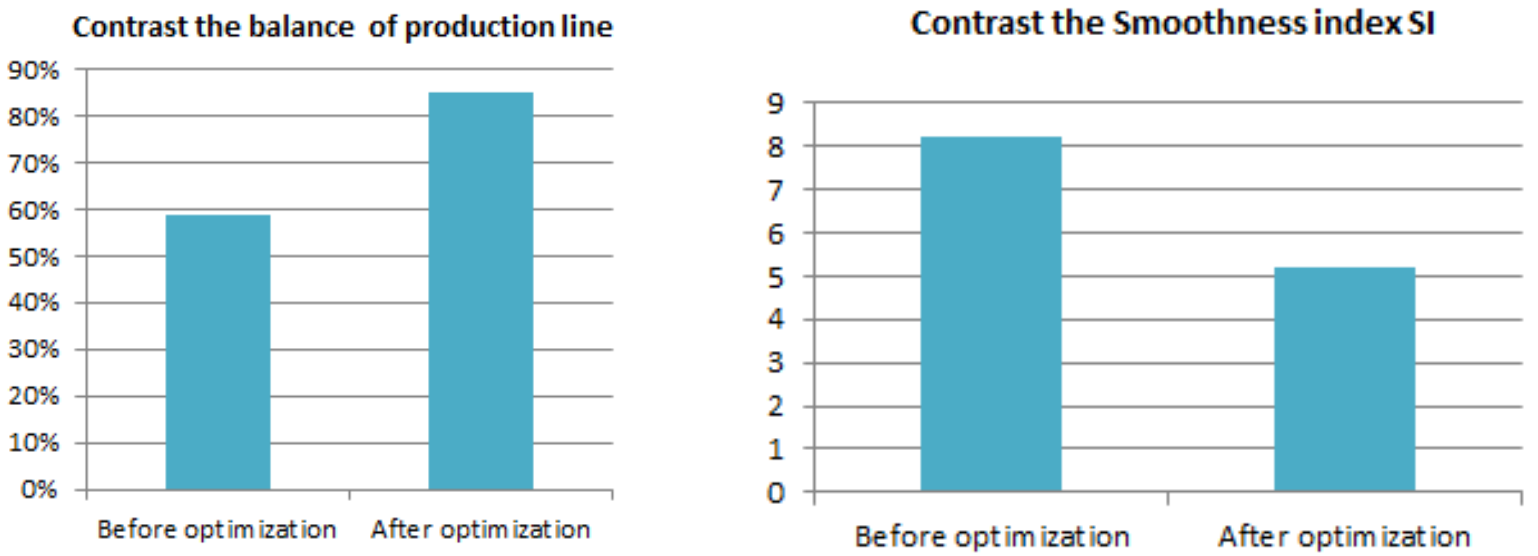

Figure 1 Contrast the balance of production line Figure 2 Contrast the Smoothness index SI

\section{References}

[1]YI Shu-ping, GUO Fu. Fundamental Industrial Engineering[M]. Beijing: China Machine Press, 2007

[2]ZHU Zhen-jie. Study on Mechanical Products Assembly Line Balancing Optimal Algorithms[D]. Shandong: Shandong University, 2010

[3]WU Xiao-yan. Research on the Assembly Production Line Balance [D]. Shanghai: Shanghai Jiao Tong University, 2007

[4]LAN Xiu-ju, CHEN Yong, TANG Hong-tao. Balancing and Continuous Improvement of SMT Production Line [J]. Shanghai: Industrial Engineering and Management, 2006: 109-111

[5]YANG Jie-dan, TANG Tie-zhuang, LI Wei-hong, LIU Wei-guang. Analysis of Improvement of Production Line Balancing [J]. Hubei Province: Journal of Green Science and Technology, 2011: 180-182. 